Annals of Warsaw University of Life Sciences - SGGW

Land Reclamation No 45 (2), 2013: 143-157

(Ann. Warsaw Univ. of Life Sci. - SGGW, Land Reclam. 45 (2), 2013)

\title{
Estimation of physical and mechanical properties of cohesive soil stabilized by hydratized lime addition
}

\author{
WOJCIECH SAS ${ }^{1}$, ANDRZEJ GŁUCHOWSKI ${ }^{2}$, JAROSŁAW MARGIELSKI ${ }^{3}$, \\ Water Center Laboratory ${ }^{1}$, Department of Geotechnical Engineering ${ }^{2}$, Department of Production \\ Engineering ${ }^{3}$ \\ Warsaw University of Life Sciences - SGGW
}

\begin{abstract}
Estimation of physical and mechanical properties of cohesive soil stabilized by hydratized lime addition. Process of chemical stabilization of cohesive soils influences its mechanical properties, also in the case of soil cohesion. Road constructions consist of few layers which have various mechanical properties and this creates the need for better understanding the impact of chemical stabilization on soil as a layer of road. For the purposes of this article, tests were carried out in order to establish physical and mechanical properties, especially the penetrating resistance CBR test. The main aim of this paper was to estimate the cohesion of the soil, which was sandy-silty clay stabilized with hydrated lime.
\end{abstract}

Key words: lime stabilization, CBR, compressive strength, cohesion, unconfined compressive strength, bearing capacity

\section{INTRODUCTION}

Problematic soils used as a base of pavement are usually improved, by changing their properties due to physical and chemical stabilization. This technique has been used for many years and has proofed to be generally effective when it comes to stabilizing pavement layers. Different soil types have been treated with lime and cement additions and these stabilization agents were assumed as most effective (Little 1995).
The laboratory and field findings give reasonable data to put stabilization as one of major techniques of improving soil mechanical parameters.

One of the most common methods of testing soil, widely applied by engineers, is a CBR test. This simple method gives data, which is then used to design of pavements. Although this method is based on empirical dependences, it is still useful for design process. Interesting fact of substantial rise of CBR value from $1 \%$ for non-stabilized soil to $30-50 \%$ for stabilized soils creates many doubts about proportional to CBR test increase of other mechanical properties even after considering the rich experience in stabilization process (Kleyn 1955, Little and Nair 2009).

There are two basic chemical reactions which take place in case of stabilization. First, there are short-term reactions, including cation exchange and flocculation. Lime in this case is a strong alkaline base, which is case of a base exchange. Calcium ions remove sodium, potassium and hydrogen cations and also change electrical charge density around the clay particles. This reaction causes increase in the interparticle attraction and is the reason behind the processes 
flocculation and aggregation with a subsequent drop of the plasticity of the soils (Ismaiel 2006, Al-Mukhtar et al. 2010).

Secondly, there are long-term reactions, including pozzolanic reaction, where calcium reacts with soluble alumina and silica in presence of water. This reaction produces stable calcium silicate hydrates, calcium aluminate hydrates and calcium alumino-silicate hydrates. This compounds generate long-term strength and improve geotechnical properties (Ismaiel 2006, Al-Mukhtar et al. 2010).

This two types of reaction are strictly bounded with amount of clay fraction, moisture and value of lime addition. That variables are coming only from material properties and composition of mixture. Important factor caused by above properties is time dependent stabilization process. Measurement of mechanical behavior by basing on CBR bearing capacity factor seems inadequately and unconfined compressive strength test is able to give more valuable data describing strength properties which can be easily apply in design of pavements.

\section{LITERATURE REVIEW}

Chemical additives as lime or cement tested are designed to combine with the soil to change the texture, rise strength and reduce swell characteristics. When the stabilization medium containing free calcium hydroxide are mixed with the soil, the calcium is the cause that the clay particles flocculate into a sand-like structure and thereat reduces the plasticity of the soil (Milburn and Parsons 2004).

Reduction in plasticity, which is called modification, drops down the shrink/swell characteristics of the soil. Soil stabilization base on the effects from modification with an additional strength gain.

Soil stabilization contains all the effects of modification with an additional long-term strength rise as was mentioned above. Soil conditions and mineralogical properties have a greater role for soil stabilization than modification (Little 1995). The magnitude of soil stabilization is usually measured by the increase in strength as determined from unconfined compression testing.

Stabilization with calcium hydroxide agent increases the $\mathrm{pH}$, resulting the silica and alumina in the clay particles to become solvable and interact with the calcium in a pozzolanic reaction. A pozzolanic reaction between silica and alumina in the clay particles and calcium can form a cemented conformation that grow the strength of the stabilized soil. Residual calcium must remain in the structure to bound with the available silica or alumina and keep the $\mathrm{pH}$ at high level to provide the pozzolanic reaction (Ferguson 1993).

The CBR value is also related to the Plastic Index (PI). For non-stabilized a relating system, which refers CBR value to PI (Kleyn 1955), was created. With the decrease of PI value and the rise of grading modulus, the CBR factor was increased.

For better understanding of increase of strength parameters in the CBR test which is bearing capacity test, another test is being sought after. In case of chemically active stabilized soils, whereas $\mathrm{pH}$ value plays important role concerning mobile calcium in flocculated aggregates, unconfined compressive 
strength test can bring suitable data to correlate the effect of static loading from CBR plunger with static loading of plate on specimen surface.

One of constants which can be obtained from unconfined compressive strength test (UCS) is cohesion. Unfortunately, due to its principles, the UCS test, where $\sigma_{3}=0$, give only approximate value of cohesion $-c$, which in this case is equal to compressive strength $-\tau_{f}$. This fact does not allow us to obtain the right value of cohesion.

In order to find cohesion of material, use of estimated equation is needed. During the last research, non-linear failure criterion for stabilized materials presented by equation (1), is attained by means of triaxial shear tests (Sharma et al. 2011, Azadegan et al. 2013):

$\tau=P_{a}\left(0.0115 \frac{q_{u}}{P_{a}}+1.242\right)\left(\frac{\sigma+0.035 q_{u}}{P_{a}}\right)^{n}$

where $\tau$ is the shear strength, $q_{u}, P_{a}$ and $\sigma$ are differential axial pressure, atmospheric pressure and confining pressure (in $\mathrm{kPa}$ ) respectively. Parameter $n$ carries from 0.5 to 1.0 .
In the case of unconfined compressive test, the amount of $\sigma$ equals zero. From this statement we can assume that value of shear strength $-\tau$ is equal to the amount of real cohesion of tested material, this relation presented by equation (2):

$$
C_{r}=P_{a}\left(0.0115 \frac{q_{u}}{P_{a}}+1.242\right)\left(\frac{0.035 q_{u}}{P_{a}}\right)^{n}
$$

The value of $q_{u}$ was obtained from UCS and later used to obtain value of cohesion, which was used for data analysis from CBR test.

\section{MATERIAL AND METHODS}

Soil used to conduct the tests was collected from a 60-cm-deep earthwork construction site. Conducted tests of sieve and aerometric (Bouyoucos method, using a modification made by Casagrande) analysis led to classification of material as sandy-silty clay (sasiCl), in accordance with PN-EN ISO 14688:2006. Test results are shown in Figure 1. Studies performed under existing Polish standards (PN-B-02480, PN-B-02481,

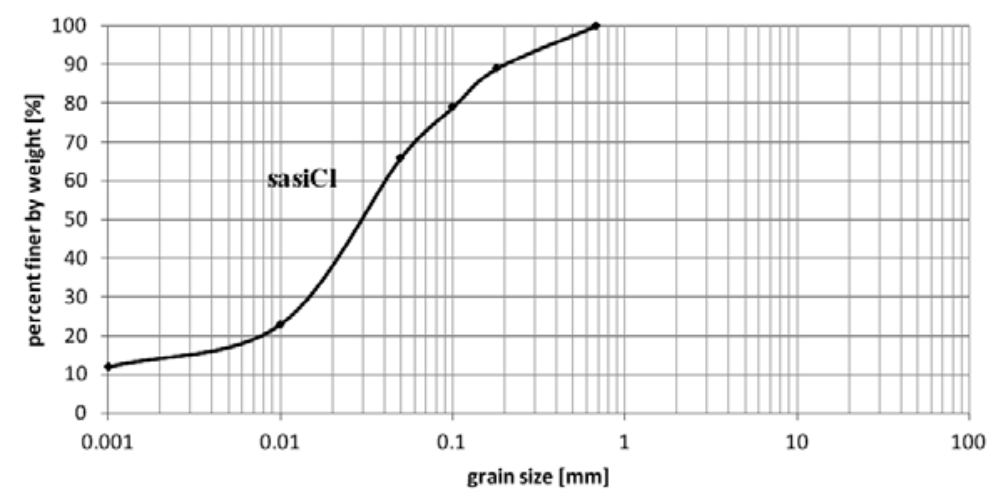

FIGURE 1. Particle size distribution of tested soil 
PN-B-03020, PN-B-06050, PN-S-02201, PN-S-02205, PN-S-96011, PN-EN ISO 14688:2a, PN-88/B-04481). Figure 2 presents the samples during tests.
Preformed CBR and UCS tests specimens was prepared with account in existed Polish codes procedures. Compaction in CBR mould was performed to obtain $0.59 \mathrm{~J} / \mathrm{cm}^{3}$ compaction energy with including optimal moisture content.

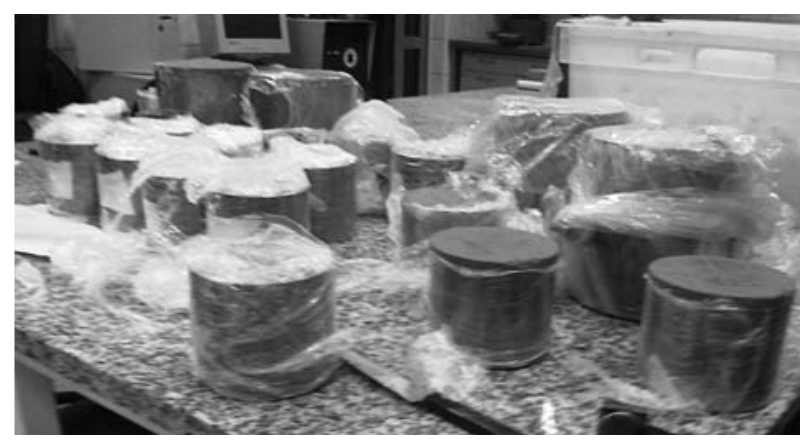

FIGURE 2. Samples after the Proctor test

Stabilization medium used for stabilization was hydratized lime $\mathrm{Ca}(\mathrm{OH})_{2}$. Hydratized lime was obtained as common industrial package from ordinary building material store.
Estimation of liquid limit was also performed. Tests were conducted in Casagrande apparatus, with the use of soil paste. On the basis of six tests performed with varying moisture content, plot of liquid limit was made (Fig. 3).

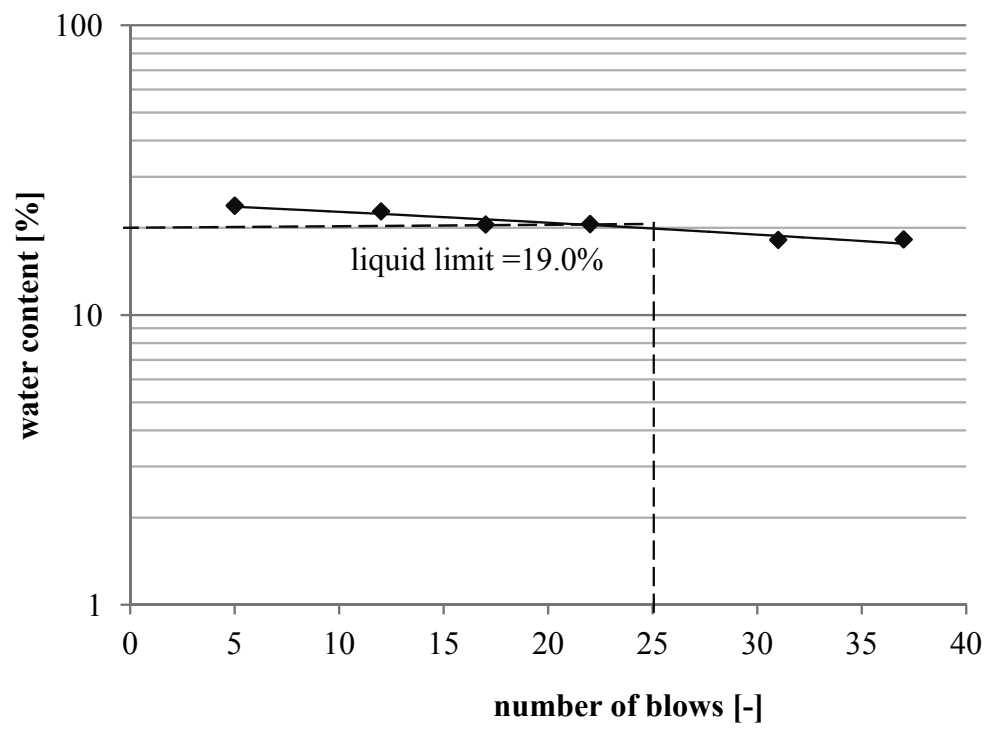

FIGURE 3. Liquid limit estimation test results 
Estimated liquid limit was $19.0 \%$. Such range of liquid limit classifies this soil as clay with low plasticity.

\section{RESULTS}

Optimum moisture content was estimated by Proctor test. The test was conducted by compaction in the Proctor mold, which volume equaled $2.2 \mathrm{dm}^{3}$, by using standard energy of compaction, which is $0.59 \mathrm{~J} / \mathrm{cm}^{3}$. Test results are presented in Figure 4. Optimum moisture content for sandy-silty clay was $10.6 \%$ and maximum dry density of optimum moisture content reached $2.16 \mathrm{~g} / \mathrm{cm}^{3}$.

The Proctor test was also performed for soil stabilized with lime $\mathrm{Ca}(\mathrm{OH})_{2}$. Tests were conducted for soil with 5 , 8 and $10 \%$ of lime content. Results are presented in Figures 5 and 6.

Results of the Proctor test present the impact of lime content on optimum moisture content and also on maximum dry density of mixture as in previous paper (Sas et al. 2013). For sandy-silty clay with $5 \%$ added lime, optimum moisture content was $9.96 \%$, while maximum dry density reached $2.15 \mathrm{~g} / \mathrm{cm}^{3}$. For specimens with $8 \%$ lime content and optimal moisture content at $12.07 \%$, maximum dry density was equal $2.18 \mathrm{~g} / \mathrm{cm}^{3}$. Last test conducted on the soil with $10 \%$ lime content gave the following results: optimal moisture content was equal $12.10 \%$ and maximum dry density was equal $2.13 \mathrm{~g} / \mathrm{cm}^{3}$. Figure 6 presents a 3D visualization of these three variables. By analyzing the graph surface, it is possible to estimate an equation containing variables denoting water and lime content. Equation (1) presents formula for calculating the density of soil $(z)$ under with varying lime $(y)$ and water content $(x)$ expressed in as a percentage value.

$$
\begin{aligned}
& z=a+b x+c x^{2}+d x^{3}+e x^{4}+f x^{5}+g y+ \\
& +h y^{2}+i y^{2}
\end{aligned}
$$

Where letters from a to $\mathrm{i}$ are constants: $a=-0.79725331 ; b=1.65477032$; $\mathrm{c}=-0.39201531 ; \mathrm{d}=0.045130743$; $\mathrm{e}=-0.00246416 ; \mathrm{f}=0.00000509$;

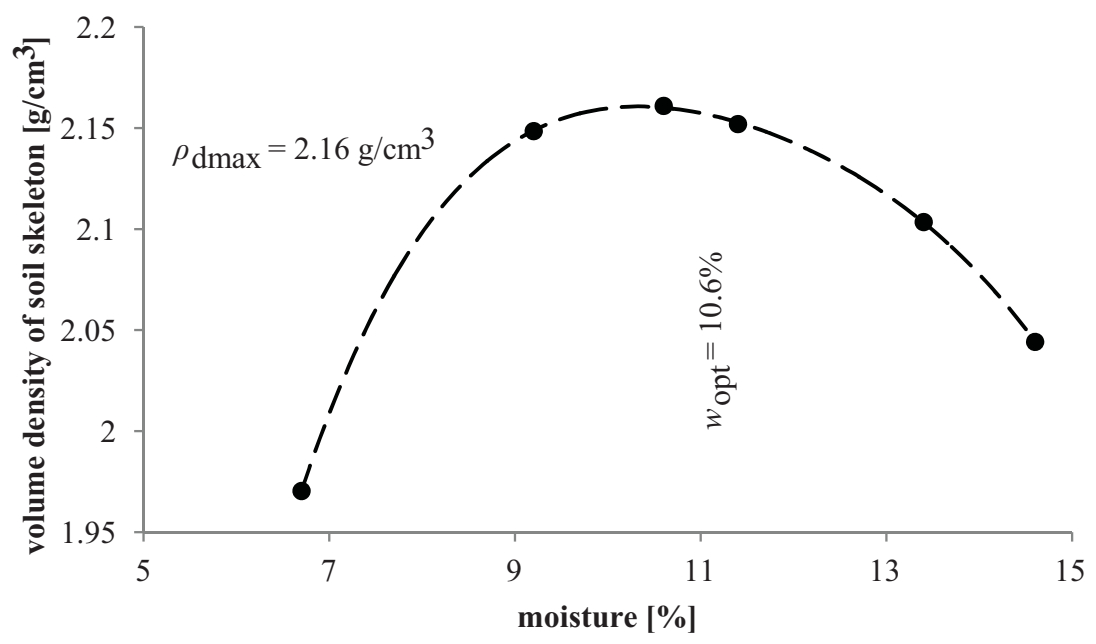

FIGURE 4. The Proctor test results for sandy-silty clay 
$\mathrm{g}=-0.00317027 ; \mathrm{h}=0.001506883 ; \quad$ makes it possible to establish the optimal $\mathrm{i}=-0.00015242$. For this equation, the water and lime content for tested sandy$\mathrm{R}^{2}$ value amounts to 0.845 . Equation (3) -silty clay, by establishing maximum dry

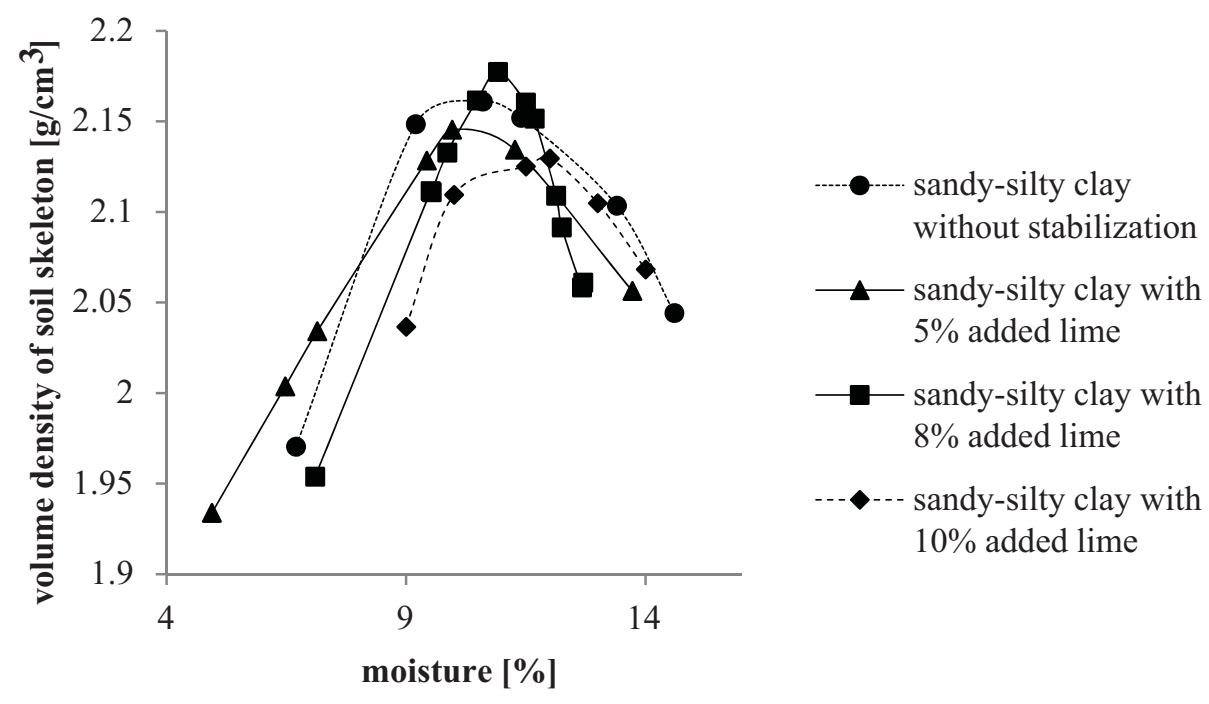

FIGURE 5. Results of the Proctor test for soil with varying lime content

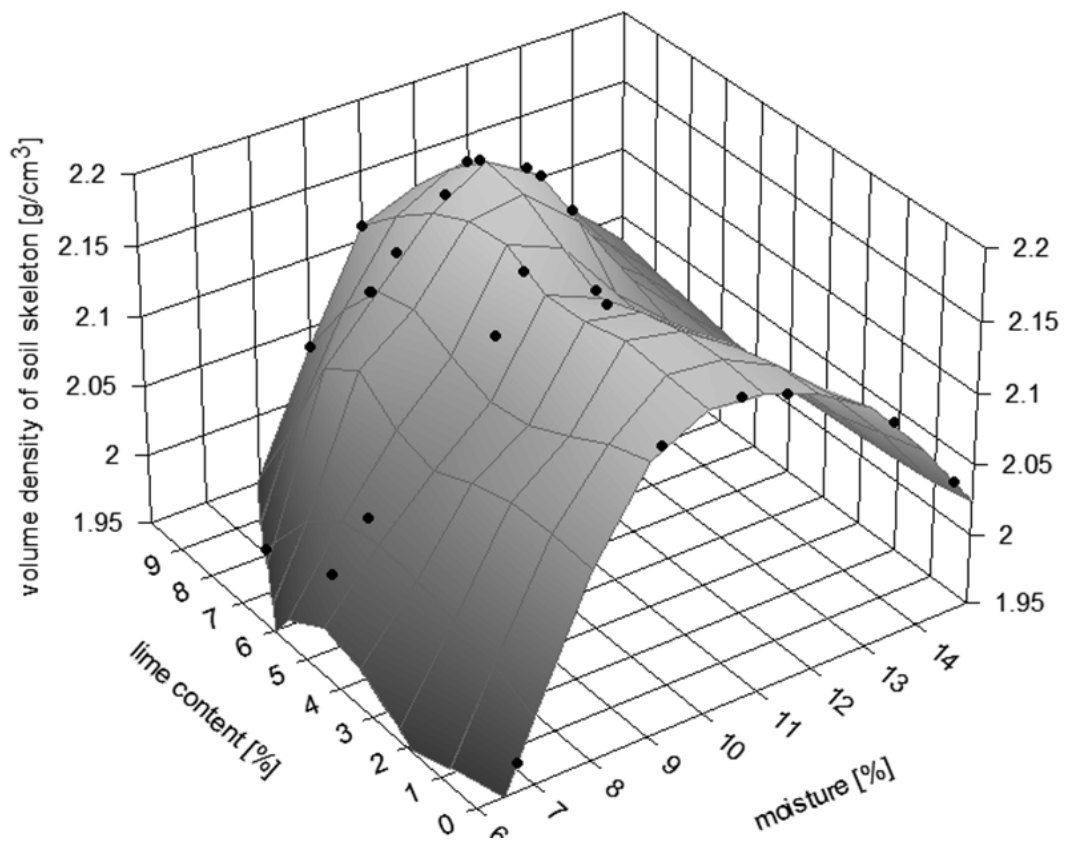

FIGURE 6. 3D plot of specimen dry density in soil with varying lime and water content 


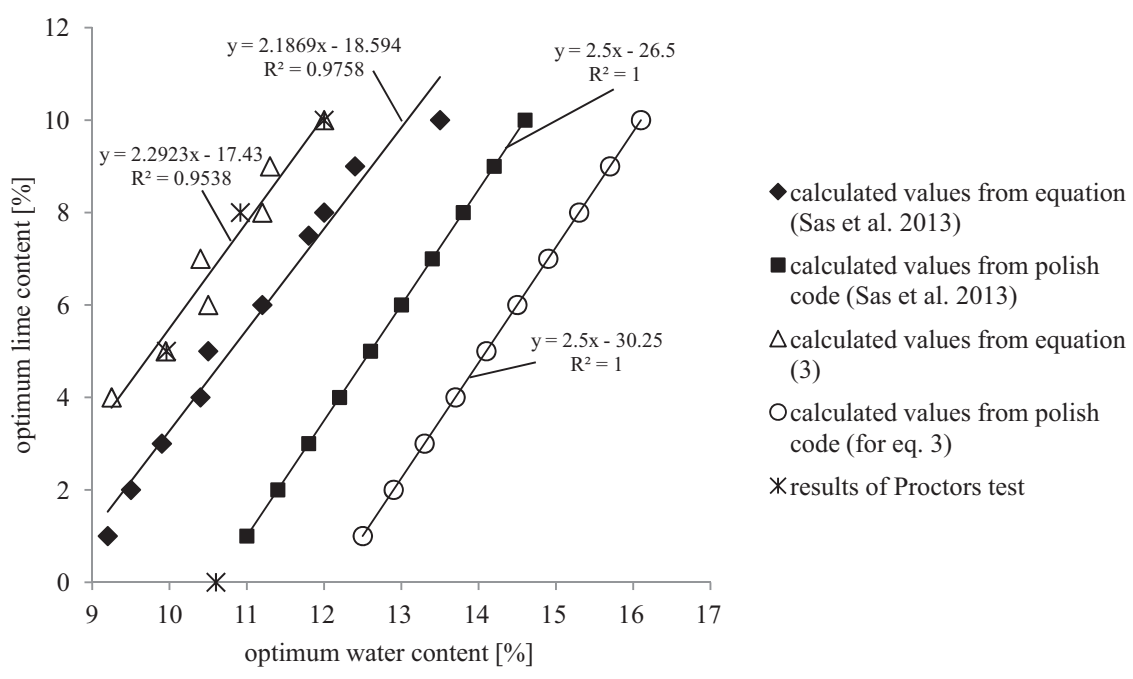

FIGURE 7. Results of optimal condition calculations for the mixture of sandy-silty clay, water and lime, and calculations based on the Polish standard and previous results

density. Comparison of optimal moisture content by correlation with equation (1) from test results by Sas et al. (2013) and with calculations based on the Polish standard PN-S-96011 are presented in Figure 7.

Correlation of the equation (1) which was mentioned above is:

$z=\frac{\mathrm{a}+\mathrm{c} x+\mathrm{e} y+\mathrm{g} x^{2}+\mathrm{i} y^{2}+\mathrm{k} x y}{1+\mathrm{b} x+\mathrm{d} y+\mathrm{f} x^{2}+\mathrm{h} y^{2}+\mathrm{j} x y}$

Where, letters from a to $k$ are constants: $\mathrm{a}=1.830147354 ; \mathrm{b}=-0.21419130$; $\mathrm{c}=-0.386028110 ; \mathrm{d}=0.135043775$; $\mathrm{e}=0.258866051 ; \mathrm{f}=0.014331182$ $\mathrm{g}=0.026577656 ; \mathrm{h}=0.000321902 ;$ $\mathrm{i}=0.000145624 ; \mathrm{j}=-0.013335690$; $\mathrm{k}=-0.025355170$. Presented formula is designed for calculating the density of soil $(z)$ with varying lime $(y)$ and water content $(x)$ expressed as a percentage value.
Calculations of optimum water content and lime addition based on the equation formulated on the basis of the Polish standard (PN-S-96011) were as follow:

$w_{\mathrm{opt}}^{w}=w_{\mathrm{opt}}^{g}+1.5+0.4 D$

where $w_{\mathrm{opt}}^{w}$ is optimum moisture content for the mixture, constant expressed as a percentage value, $w_{\mathrm{opt}}^{g}$ is optimum moisture content before the addition of lime and $D$ stands for lime content as a percentage value. Differences between results from testing of materials and calculation based on the Polish standards came from particle size distribution. Impact of silt fraction could be the reason behind the decrease of optimal moisture content, while according to the results of equation (5) optimal moisture should increase.

Compressive strength of specimens was also tested during various stages of stabilization, after 7 and 28 days, with 
variant moisture content. Obtained results are presented in Figures 8 and 9. Specimens were prepared in Proctors mould in optimal moisture content and compressive strength tests were performed on stress-strain registration controller. Obtained data during the tests was used to analysis of same relationship from CBR test.

Figure 8 presents compressive strength coefficient after stabilization with change of optimum moisture content with 5\% lime added. Plot of this data clearly shows that compressive strength coefficient depends on the stabilization time. An important impact of moisture content can also be noted. Compressive strength coefficient rises, until moisture content is around $9.69 \%$. Then, coefficient is constant until moisture content reaches $13.8 \%$. That indicates the importance of careful application of water during the stabilization of soils.

Equation (6) presents formula for calculating the compressive strength of sandy-silty clay $(z)$ with varying time after stabilization $(y)$ and water content $(x)$, expressed as a percentage value.

$$
z=\frac{a+b x+c x^{2}+d x^{3}+e \ln y}{1+f x+g x^{2}+h \ln y}
$$

Where, letters from a to $\mathrm{k}$ are constants: $a=0.697876741 ; b=-0.21232403$; $\mathrm{c}=0.021214195 ; \mathrm{d}=-0.0006784$; $\mathrm{e}=0.012583939 ; \mathrm{f}=-0.2156206$; $\mathrm{g}=0.012110767 ; \mathrm{h}=0.011178188$. For this equation the $R^{2}$ value is 0.998 .

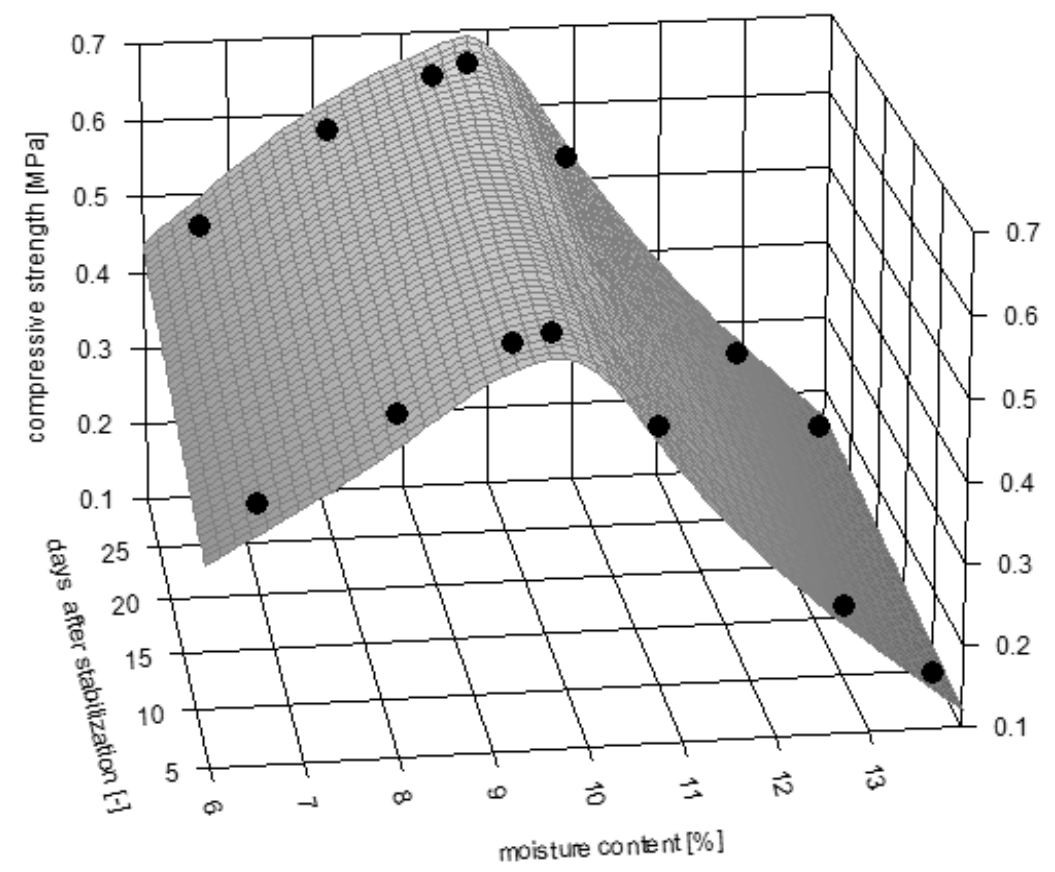

FIGURE 8. 3D plot of specimen compressive strength in soil with varying time of stabilization and water content for specimen with $5 \%$ lime added 


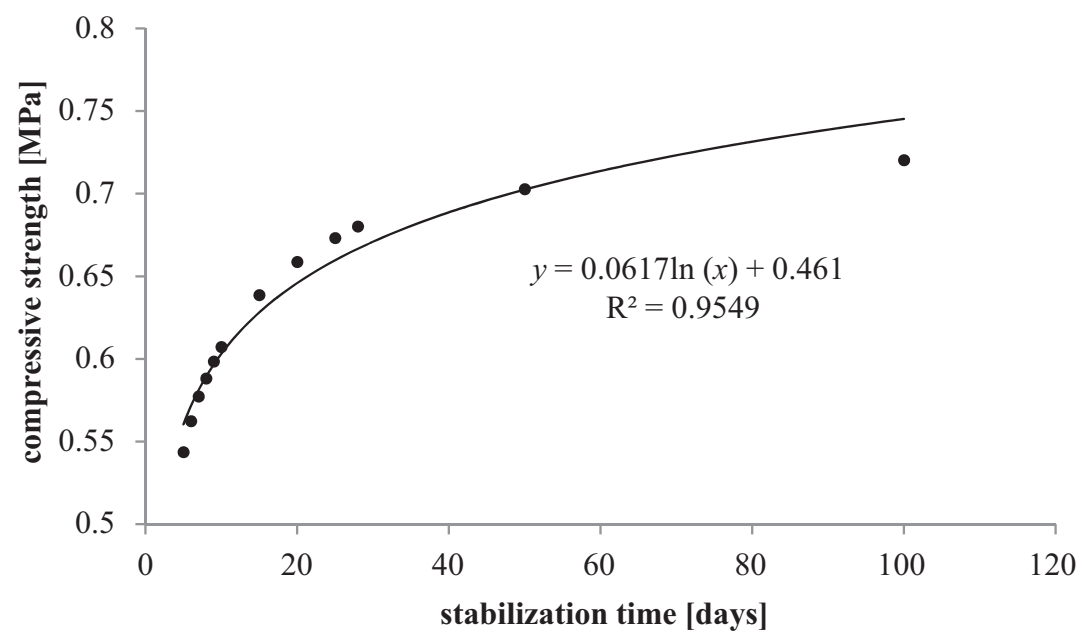

FIGURE 9. Results from calculating maximal compressive strength of stabilized soil with $5 \%$ added lime sandy-silty clay in various stage of stabilization

Equation (6) was applied to find maximal compressive strength in various stage of stabilization in optimal moisture content. Results are presented on Figure 9.

Optimum moisture content for maximal compressive strength ranges from 9.4 to $9.9 \%$. Compressive strength coefficient for these conditions reaches $0.543 \mathrm{MPa}$ after 5 days from stabilization, to $0.720 \mathrm{MPa}$ after 100 days from stabilization, which is the highest predicted coefficient for lime stabilized sandy-silty clay with low liquid limit and high silt content. On basis of Figure 9 it can clearly be seen that $91 \%$ of compressive strength is mobilized during the first 28 days.

Figure 10 presents results of cohesion calculation, based on equation presented by Sharma (2). Cohesion coefficient changes with moisture content. Impact of time of stabilization is in this case less important.

Equation (7) presents formula for calculating the cohesion of sandy-silty clay $(z)$ with varying time after stabilization

(y) and water content $(x)$, expressed in as a percentage value.

$$
z=\frac{\mathrm{a}+\mathrm{b} \ln x+\mathrm{c}(\ln x)^{2}+\mathrm{dl}(\mathrm{n} x)^{3}+\mathrm{e} y}{1+\mathrm{f} \ln x+\mathrm{g}(\ln x)^{2}+\mathrm{h} y}
$$

Where, letters from a to $\mathrm{k}$ are constants: $a=193.1540148 ; b=255.725066$; $\mathrm{c}=112.7577755 ; \mathrm{d}=-16.4023046$; $\mathrm{e}=0.022050962 ; \mathrm{f}=-0.9105299$; $\mathrm{g}=0.213597437 ; \mathrm{h}=0.000231214$. For this equation the $R^{2}$ value is 0.999 .

Equation (7) was applied to find maximal cohesion in various stage of stabilization in optimal moisture content. Results are presented on Figure 11.

Optimum moisture content for maximal cohesion ranges for maximal compressive strength from 9.4 to $9.9 \%$. Cohesion for these conditions reaches from $55.9 \mathrm{kPa}$ after 5 days after the stabilization to $70.2 \mathrm{kPa}$ after 100 days from stabilization, which is the highest predicted 


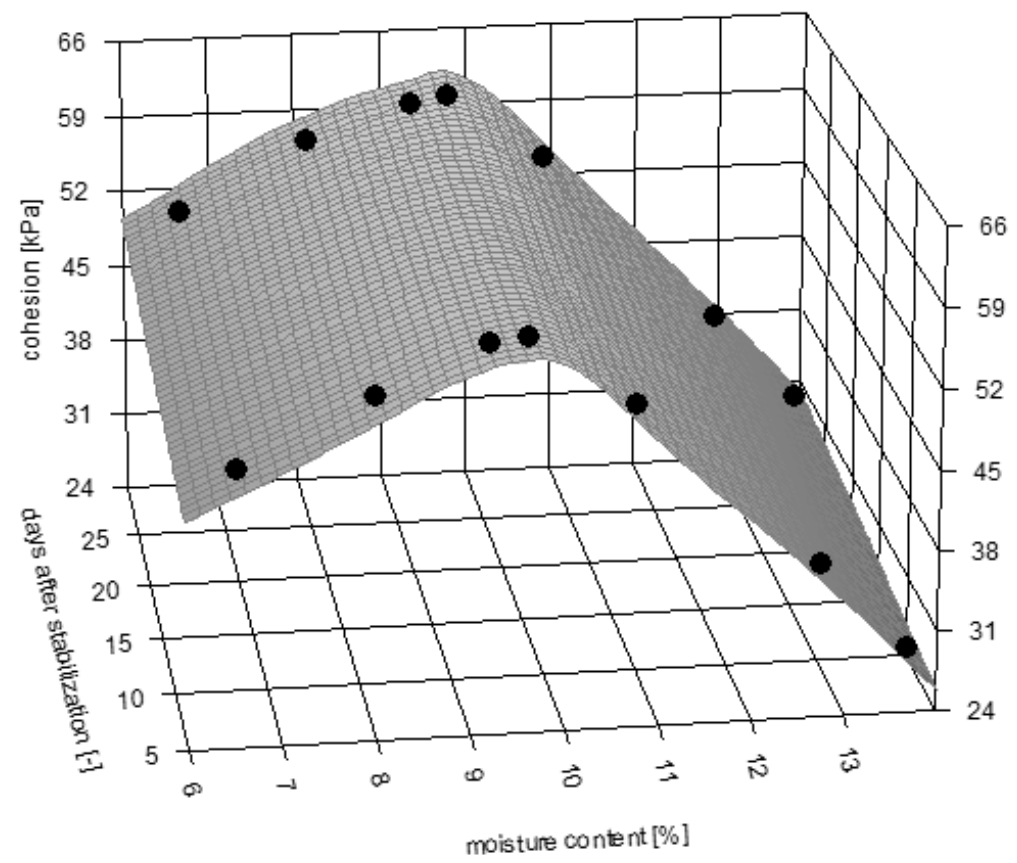

FIGURE 10. 3D plot of specimen cohesion with varying time of stabilization and water content for sandy-silty clay specimen with $5 \%$ lime added

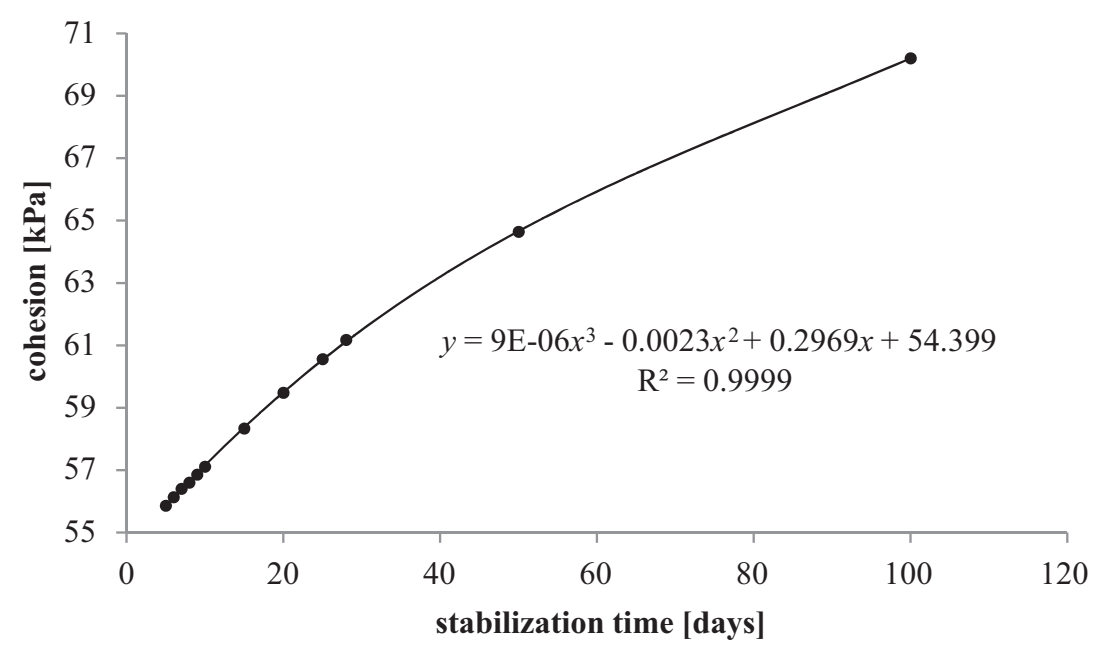

FIGURE 11. 3D plot of specimen cohesion in varying time of stabilization and water content, for specimen sandy-silty clay with $5 \%$ lime added 
coefficient for lime stabilized sandy-silty clay with low liquid limit and high silt content.

For the purpose of wider application of relationship between value of the cohesion and results from unconfined compressive strength test, CBR tests were conducted.

Figure 12 presents results of CBR test for $5 \%$ lime stabilized sandy-silty clay in comparison with the UCS test results. during the UCS test. Penetration for this test was 2.2 times higher. Results of this relation are presented by Figure 13.

In order to confirm this observation, CBR and UCS tests were performed for $8 \%$ lime stabilized sandy-silty clay after 7 days. Results of these studies are presented by Figures 14 and 15, which refer to Figure 12 and 13 respectively.

Figure 15 presents assumption of stress and displacement in the same

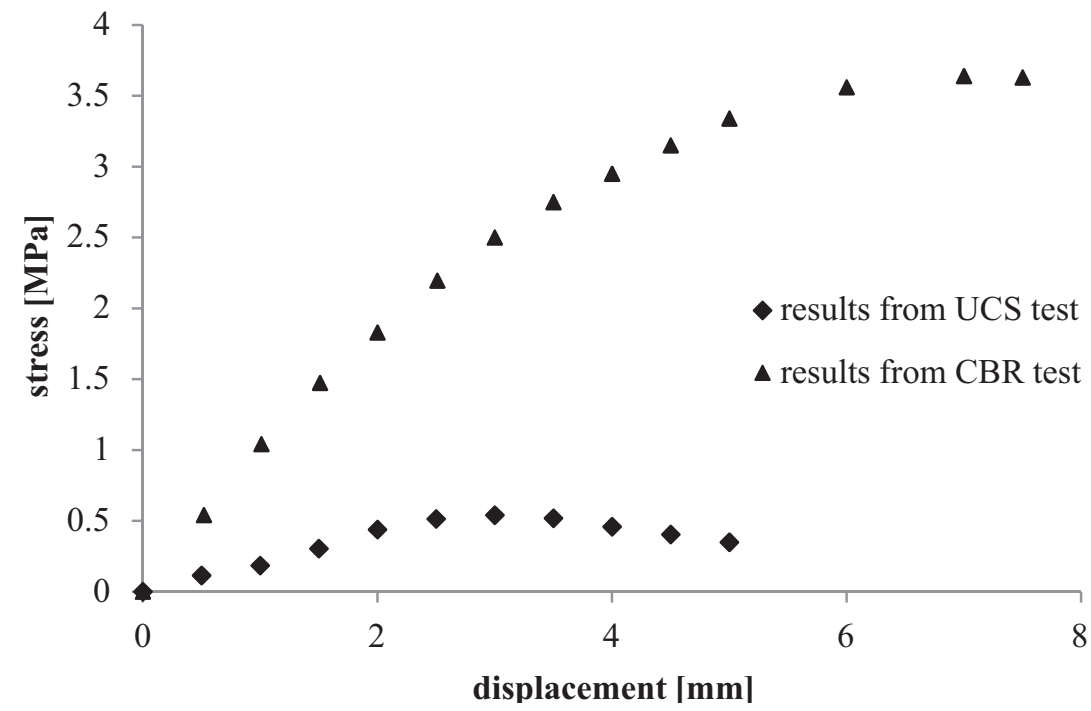

FIGURE 12. Results of CBR test and UCS test for stabilized with 5\% lime added sandy-silty clay 7 days after the stabilization

CBR tests were conducted until loaded specimens reached their bearing capacity which the result of slightly decreased force due to raised displacement. During the CBR tests, the CBR value was established as being $31.8 \%$ for $2.54 \mathrm{~mm}$ penetration and $30.6 \%$ for $5.08 \mathrm{~mm}$ penetration. By analyzing stress and displacement range some assumption of maximal stress and displacement range were estimated. Stress rate was 6.5 times higher during the CBR test than ranges as for specimen stabilized with 5\% added lime. Previous research points to the relationship between bearing capacity and compressive strength for natural soils (Coduto et al. 2010). For stabilized soils bearing capacity (obtained from CBR test) $q_{p(C B R)}$ is also correlated with unconfined compressive test $q_{u}$. This dependency is presented by the equation (8):

$q_{u}=\frac{q_{p(C B R)}}{6.5}$ 


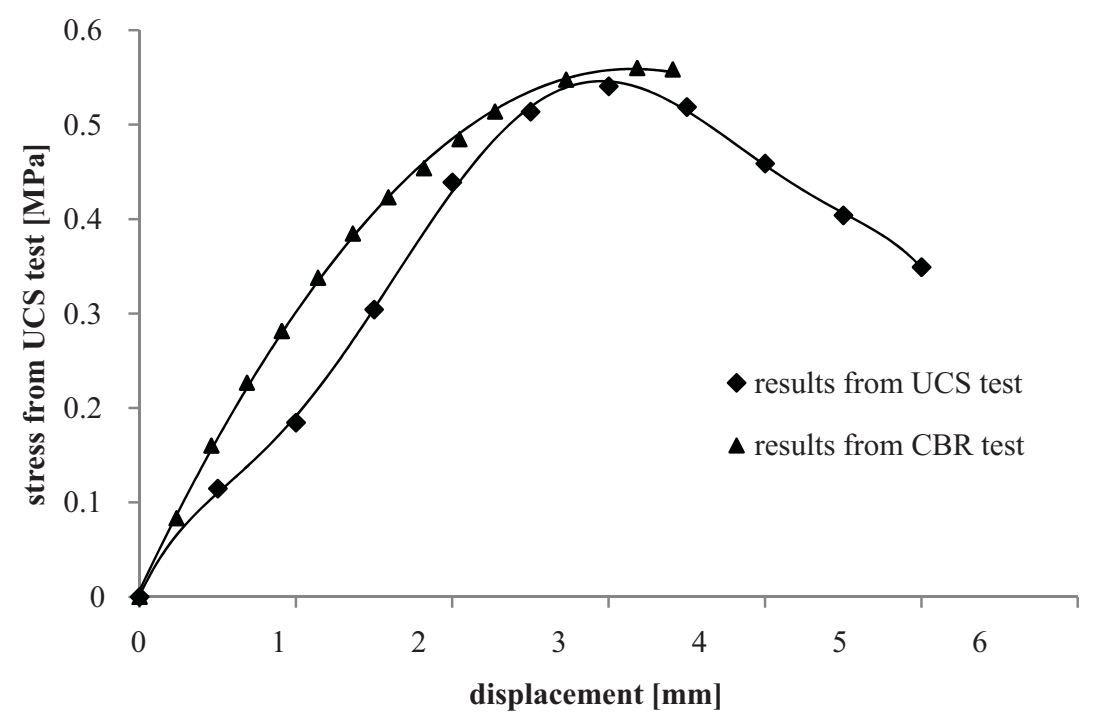

FIGURE 13. Results of CBR and UCS tests with accounted assumption of stress and displacement range

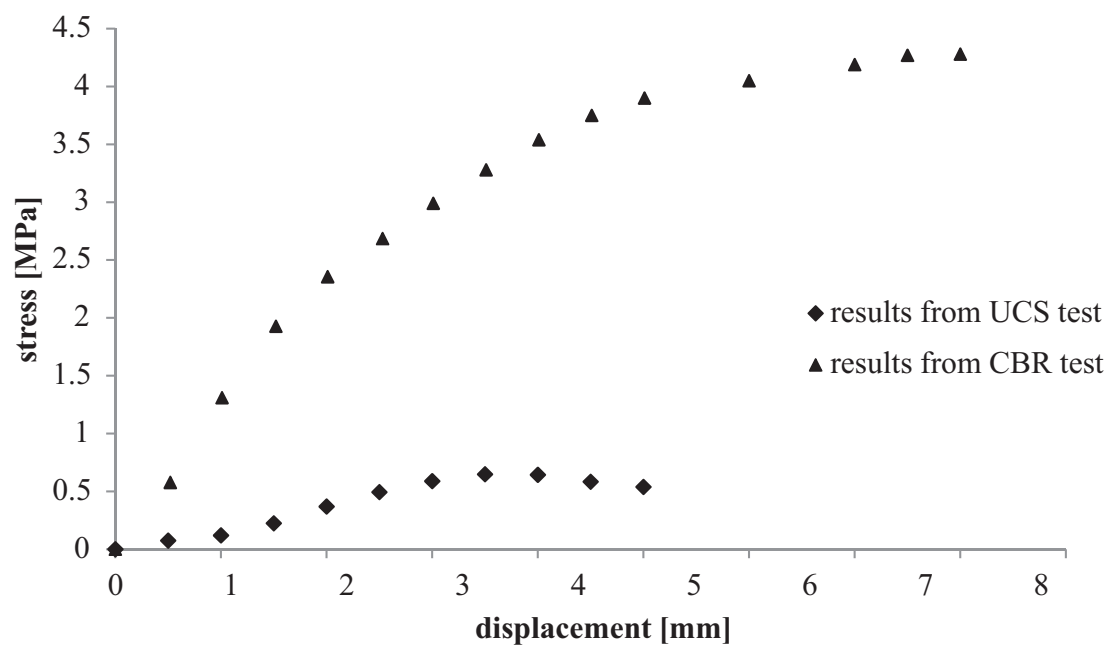

FIGURE 14. Results of CBR test and UCS test for stabilized sandy-silty clay with $8 \%$ lime added 7 days after stabilization

Equation (8) can be useful for the cohesion estimation with the neglect of UCS test. By including the equation (8) $C_{r}=P_{a}\left(0.0177 \frac{q_{p(C B R)}}{P_{a}}+1.242\right)\left(\frac{0.228 q_{p(C B R)}}{P_{a}}\right)$ in the cohesion formula (2), one obtains the following dependence (9): 


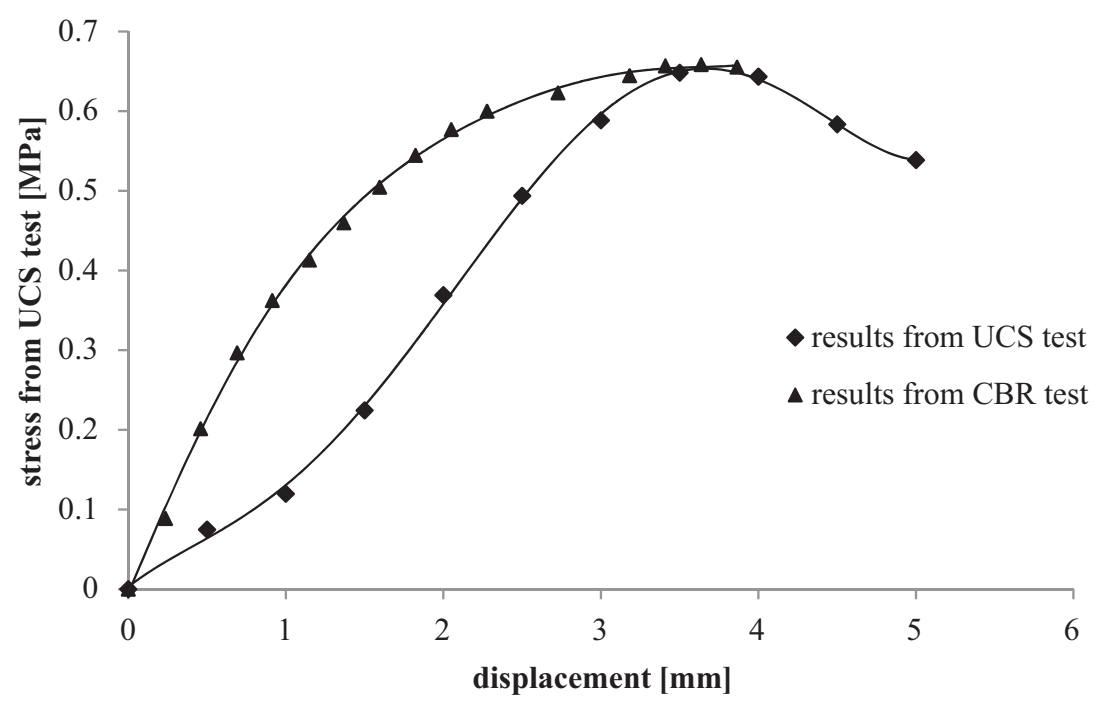

FIGURE 15. Results of CBR and UCS tests with accounted assumption of stress and displacement range

This relation served for back analysis and in order to designate cohesion on the basis of CBR test results. The cohesion in case of the UCS tests for sandysilty clay stabilized with addition of 5\% lime after 7 days from stabilization was $56.57 \mathrm{kPa}$. Back analysis of this soil from CBR test estimated the cohesion value as being equal to $55.62 \mathrm{kPa}$. For stabilized sandy-silty clay with $8 \%$ lime results were 59.90 and $60.37 \mathrm{kPa}$ respectively.

\section{CONCLUSIONS}

On the basis of the research conducted in this paper and analysis of the mechanical properties of sandy-silty clay stabilized with lime, the following conclusions were made:

1. Optimum moisture content obtained during the Proctor test for low liquid limit sandy-silty clay is different than that obtained using than the Polish standard.

2. For low cohesive soils stabilized with lime, new method of calculating the cohesion from UCS and CBR tests by equations (2), (8) and (9) for optimum water addition was proposed.

3. Equation (8) confirms strong relationship between compressive strength and bearing capacity (in CBR test) and new formula to calculate this phenomena has been proposed.

4. Equations (3) and (4) can be used as an easy tool to obtain optimum water content and with known lime addition in varying time after stabilization to find mechanical properties of stabilized soil with low liquid limit and high percentage of silt.

5. The first 28 days after stabilization are most important for the mechanical properties of soils stabilized with lime. 


\section{REFERENCES}

AL-MUKHTAR et al. 2010: Behavior and mineralogy changes in lime-treated expansive soil at $50^{\circ} \mathrm{C}$. Applied Clay Science 50(2): 199-203.

AZADEGAN O., YAGHOUBI E., Li J. 2013: Evaluation of the Performance of Lime and Cement Treated Base Layers in Unpaved Roads. The Electronic Journal of Geotechnical Engineering 18: 1593-1602.

CODUTO D.P., MAN-CHU R.Y., KITCH W.A. 2010: Geotechnical Engineering: Principles \& Practices. Prentice Hall, New York.

FERGUSON G. 1993: Use of self-cementing fly ash as a soil stabilizing agent. Geotechnical Special Publication 36, ASCE, New York: 1-15.

ISMAIEL H.A.H. 2006: Treatment and Improvement of the Geotechnical Properties of Different Soft Fine-grained Soils Using Chemical Stabilization. Shaker, Aachen.

KLEYN S.A. 1955: Developments in Pavement Foundation Design. The South African Institution of Civil Engineers 5(12): 286-292.

LITTLED.N. 1995: Handbook for Stabilization of Pavement Subgrades and Base Courses With Lime. Kendall Hunt, Dubuque, Iowa.

LITTLE D.N., NAIR S. 2009: Recommended Practice for Stabilization of Subgrade Soils and Base Materials. NCHRP Project 20-07, Texas.

MILBURN J.P., PARSONS R.L. 2004: Performance of Soil Stabilization Agents. Report K-TRAN: KU-01-8.

PN-88/B-04481: Grunty budowlane. Badania próbek gruntu.

PN-B-02480: Grunty budowlane - Określenia, symbole, podział i opis gruntów.

PN-B-02481: Geotechnika - Terminologia podstawowa, symbole literowe i jednostki miar.

PN-B-03020: Grunty budowlane - Posadowienie budowli - Obliczenia statyczne i projektowanie.

PN-B-06050: Geotechnika - Roboty ziemne - Wymagania ogólne.
PN-EN 1997-1: Projektowanie geotechniczne-Część 1: Zasady ogólne.

PN-EN 1997-2: Projektowanie geotechniczne - Część 1: Rozpoznanie i badanie podłoża gruntowego.

PN-EN ISO 14688:2a: Badania geotechniczne - Oznaczanie i klasyfikowanie gruntów - Część 2: Zasady klasyfikowania.

PN-S-02201: Drogi samochodowe - Nawierzchnie Drogowe - Podział, nazwy i określenia.

PN-S-02205: Drogi samochodowe - Roboty ziemne - Wymagania i badania.

PN-S-96011: Drogi samochodowe - Stabilizacja gruntów wapnem do celów drogowych.

SAS W., MARGIELSKI J., GŁUCHOWSKI A. 2013: Estimation of Mechanical Properties of Soil Stabilized by Hydratized Lime Addition. Ann. Warsaw Uni. of Life Sci., Land Reclam. 45(1): 27-39.

SHARMA R., BAXTER M.S., HUFFMAN C.D.P., MORAN W.K., VAZIRI H., 2011: Characterization of weakly cemented sands using nonlinear failure envelopes. International Journal of Rock Mechanics and Mining Science 48(1): 146-151.

Streszczenie: Określenie właściwości fizycznych imechanicznych gruntu spoistego stabilizowanego wapnem hydratyzowanym. Stabilizacja chemiczna gruntów spoistych wpływa na właściwości mechaniczne w tym na spójność gruntu. Konstrukcje drogowe złożone $\mathrm{z}$ wielu warstw materiałów mają różne właściwości mechaniczne. $\mathrm{Z}$ tego powodu istnieje potrzeba lepszego zrozumienia wpływu stabilizacji na grunt użyty do konstrukcji drogi. $\mathrm{W}$ artykule podjęto badania mające na celu określenie właściwości fizycznych i mechanicznych gruntu. Wykonano badania wytrzymałościowe i badania nośności CBR gruntu. Celem badań było określenie na tej podstawie zmiany spójności $\mathrm{w}$ mieszance $\mathrm{z}$ gruntu naturalnego - iłu pylastopiaszczystego $\mathrm{z}$ wapnem hydratyzowanym.

Stowa kluczowe: stabilizacja wapnem, CBR, nośność CBR warstwy konstrukcji drogowej, wytrzymałość na ściskanie, spójność, wytrzymałość na ściskanie, nośność gruntu 
MS. received December 2013

\author{
Authors' address \\ Wojciech Sas \\ Laboratorium - Centrum Wodne \\ ul. Ciszewskiego 6, 02-776 Warszawa, Poland \\ e-mail: wojciech_sas@sggw.pl \\ Andrzej Głuchowski \\ Wydział Budownictwa i Inżynierii Środowiska \\ SGGW \\ Katedra Geoinżynierii \\ ul. Nowoursynowska 159, 02-776 Warszawa \\ Poland \\ Jarosław Margielski \\ Wydział Inżynierii Produkcji SGGW \\ Katedra Maszyn Rolniczych i Leśnych \\ ul. Nowoursynowska 164, 02-787 Warszawa \\ Poland
}

